\title{
Human Immunodeficiency Virus RNA
}

National Cancer Institute

\section{Source}

National Cancer Institute. Human Immunodeficiency Virus RNA. NCI Thesaurus. Code C129663.

The viral RNA that originates from a human immunodeficiency virus. 